\title{
DATA REPORT: CENOZOIC NANNOFOSSILS FROM LEG 129
}

\author{
Shaozhi Mao ${ }^{2}$ and James M. Covington ${ }^{3}$
}

\begin{abstract}
Only Site 802 has recorded appreciable Cenozoic carbonate sediments during Ocean Drilling Program Leg 129 in the central Mariana Basin of the western Pacific Ocean. Calcareous nannofossils provide the best biostratigraphic information for the $360-\mathrm{m}$ Tertiary section, which consists primarily of volcaniclastic turbidites interbedded with calcareous claystone and chalk. Many samples contain significant amounts of nannofossils reworked from older sediments. An unconformity appears to be present between Cores 129-802A-32R and -33R, with upper Oligocene-lower Miocene sediments above and lower Eocene-upper Paleocene sediments below the unconformity. The sediments below the unconformity contain abundant reworked Cretaceous nannofossils.

Only one sample from Site 801 yielded nannofossils, and those consist of a mixture of Campanian-Maastrichtian and
\end{abstract} Paleogene forms.

\section{INTRODUCTION}

Of the three sites drilled during Ocean Drilling Program (ODP) Leg 129, only Site 802 yielded a significant number of Mesozoic and Cenozoic calcareous nannofossils (Fig. 1). The Mesozoic assemblages are described by Erba and Covington (in press), whereas the Cenozoic nannofossils are treated here. The section recovered at Hole $802 \mathrm{~A}$ was divided into ten lithologic units based on composition and color; detailed descriptions of these units are found in Lancelot, Larson, et al. (1990). The top of the section, lithologic Unit I, had very poor recovery and is not described further in this report. Instead, samples for this study were collected from lithologic Unit II to the uppermost part of Unit IV, which are mainly composed of volcanic sandstone, volcanic turbidites, calcareous claystone and chalk, pelagic claystone, and calcareous siltstone or sandstone (Fig. 2). We examined 153 upper Paleocene to upper Miocene (or up to ?Pliocene) samples from Holes 802A and 801 A using light microscopy, of which 34 were barren of nannofossils. One sample (129-802A-32R-1, 6-7 $\mathrm{cm}$ ) was examined using the scanning electron microscope (SEM). Very rare Tertiary forms were noted in eight samples from the uppermost Cretaceous Cores 129-802A-40R to -38R, but these are considered to be a result of downhole contamination. The present report, therefore, is based on the fossil records obtained from Cores 129$802 \mathrm{~A}-37 \mathrm{R}$ and above. A hiatus spanning the late Paleocene-early Eocene to late Oligocene-early Miocene was detected.

The low-latitude standard zonation scheme of Okada and Bukry (1980) is generally used in this paper. However, because of intensive reworking throughout the section, these zones were used mostly in combination rather than singly. The zones or intervals of combined zones are described in the "Results" section below. The ages (assigned to epochs and stages) follow the scheme proposed by Berggren et al. (1985a, 1985b).

\section{MATERIAL AND METHODS}

Depending on the amount of recovery, $2-\mathrm{cm}^{3}$ samples per section were generally collected aboard ship, and extra samples were taken when deemed necessary because lithologic breaks or other interesting

\footnotetext{
${ }^{1}$ Berger, W.H., Kroenke, L.W., Mayer, L.A., et al., 1993. Proc. ODP, Sci. Results, 130: College Station, TX (Ocean Drilling Program).

${ }^{2}$ Department of Geology, Florida State University, Tallahassee, FL 32306-3026, U.S.A.

${ }^{3}$ Florida Geological Survey, Tallahassee, FL 32304, U.S.A.
}

aspects of the core. Smear slides prepared from the raw sediments were generally examined at a magnification of $1560 \times$, and the abundance of each nannofossil species was recorded and tabulated in a range chart (Table 1 , in back pocket). In general, if possible, at least 400 specimens were identified and counted for each sample. Abundance and preservation of the total assemblage are also presented for each sample in the range chart. The various symbols used to denote species abundance are defined as follows:

$$
\begin{aligned}
& V=\text { very abundant }(>10 \text { specimens per field of view); } \\
& A=\text { abundant }(1-10 \text { specimens per field); } \\
& C=\text { common (at least } 1 \text { specimen per } 10 \text { fields); } \\
& F=\text { few (at least } 1 \text { specimen per } 100 \text { fields); and } \\
& R=\text { rare }(1 \text { specimen per } 100 \text { or more fields). }
\end{aligned}
$$

Symbols used for preservation are as follows:

$\mathrm{G}=$ good (specimens show little evidence of secondary alteration caused by etching or overgrowth);

$\mathrm{M}=$ moderate (specimens show some evidence of alteration, but species identification is not impaired); and

$\mathrm{P}=$ poor (specimens show much alteration, and identification to species level may be significantly impaired).

A complete list of all taxa observed in samples examined from Site 802 is given in the Appendix. Bibliographic references for these taxa may be found in Aubry (1986, 1989), Backman and Hermelin (1986), and Perch-Nielsen (1985). The published ranges for species cited in this report are from Perch-Nielsen (1985) unless specified otherwise.

\section{RESULTS}

\section{Hole 802A}

The Paleogene sediments recorded from Site 802 are mainly composed of volcaniclastic turbidites interbedded with calcareous claystone and chalk, and most samples from this section contain significant amounts of reworked fossils. In addition, some of the samples were taken from sediment which may have been deposited near or below the carbonate compensation depth (CCD). The effects of reworking combined with problems caused by dissolution make biostratigraphic study of the material difficult. The nannofossil assemblages are often mixtures of both in-situ and reworked fossils, which are dissolution resistant to some extent. Reworked fossils frequently dominate the total assemblage and obscure the true bio- 


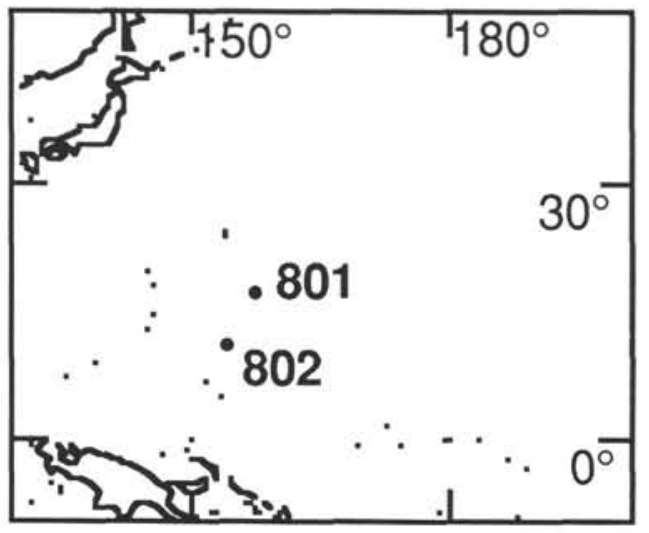

Figure 1. Location map showing Sites 801 and 802. stratigraphic relationships. When dissolution-susceptible index forms are absent, it is sometimes necessary to substitute in their stead dissolution-resistant forms that are not traditionally used as marker species. The apparent last occurrences (LOs) of marker species probably range higher in this section because of reworking and are not very useful, therefore, in defining the zonal boundaries. For this reason, only the first occurrences (FOs) of marker species can be used to delineate zones reliably. Consequently, most of the zonal intervals used here are undifferentiated combinations of adjacent zones from the Okada and Bukry (1980) scheme. As a result, the boundaries of the Eocene/Paleocene, Oligocene/Eocene, and Miocene/Oligocene cannot be determined reliably.

Samples examined from Hole $802 \mathrm{~A}$ are assigned to zones or intervals encompassing two or more adjacent zones as given below (in ascending stratigraphic order; Fig. 3). These are not new zones or new zone definitions but, rather, are intervals delineated by previously defined zones used singly or in combination.

\begin{tabular}{|c|c|c|c|c|c|c|}
\hline 등해 & $\begin{array}{l}\text { Hole } \\
802 \mathrm{~A}\end{array}$ & Age & \multicolumn{2}{|c|}{$\begin{array}{l}\text { Lithologic } \\
\text { unit }\end{array}$} & Lithology & Description \\
\hline \multirow{4}{*}{\begin{tabular}{|l}
14.0 \\
-24.3 \\
-80.4 \\
- \\
-98.9 \\
-108.3
\end{tabular}} & $3 R$ & \begin{tabular}{|l|} 
Pliocene \\
\end{tabular} & \multirow{14}{*}{ II } & \multirow{6}{*}{ Ila } & \multirow{2}{*}{ 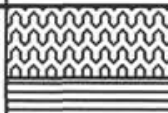 } & \multirow{6}{*}{$\begin{array}{l}\text { Tuff (volcanic turbidites) } \\
\text { with pelagic clay }\end{array}$} \\
\hline & $10 \mathrm{R}$ & \multirow{10}{*}{$\begin{array}{l}\text { early } \\
\text { middle } \\
\text { Miocene } \\
\quad \quad \mid \\
\text { early } \\
\text { Miocene }\end{array}$} & & & & \\
\hline & $11 \mathrm{R}$ & & & & & \\
\hline & $13 R$ & & & & \multirow{4}{*}{ 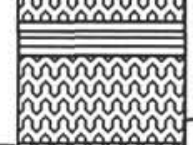 } & \\
\hline \multirow{2}{*}{$\left.\right|^{-114.3}$} & $14 \mathrm{R}$ & & & & & \\
\hline & $15 \mathrm{R}$ & & & & & \\
\hline \multirow{2}{*}{$\left.\right|^{-159.1}$} & $19 R$ & & & \multirow{8}{*}{ Ilb } & & \multirow{8}{*}{$\begin{array}{l}\text { Tuff (volcanic turbidites) } \\
\text { with calcareous claystone } \\
\text { and chalk }\end{array}$} \\
\hline & $20 R$ & & & & \multirow{4}{*}{ 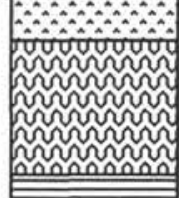 } & \\
\hline \multirow{6}{*}{$\begin{array}{l}-177.6 \\
- \\
-187.0 \\
- \\
-206.1 \\
-\end{array}$} & $21 R$ & & & & & \\
\hline & $22 \mathrm{R}$ & & & & & \\
\hline & $23 R$ & & & & & \\
\hline & $24 \mathrm{R}$ & \multirow{2}{*}{$\begin{array}{l}\text { early } \\
\text { Miocene }\end{array}$} & & & \multirow{3}{*}{ 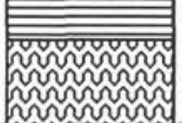 } & \\
\hline & $25 R$ & & & & & \\
\hline & $26 \mathrm{R}$ & \multirow{7}{*}{$\begin{array}{l}\text { early } \\
\text { Miocene } \\
\qquad \mid \\
\text { late } \\
\text { Oligocene }\end{array}$} & & & & \\
\hline \multirow{2}{*}{-235.1} & $27 R$ & & \multirow{10}{*}{\multicolumn{2}{|c|}{ III }} & & \multirow{10}{*}{ Nannofossil chalk } \\
\hline & $28 \mathrm{R}$ & & & & & \\
\hline \multirow{5}{*}{-273.8 } & $29 \mathrm{R}$ & & & & & \\
\hline & $30 R$ & & & & & \\
\hline & $31 \mathrm{R}$ & & & & & \\
\hline & $32 R$ & & & & & \\
\hline & $33 R$ & \multirow{4}{*}{$\begin{array}{l}\text { e. Eocene - } \\
\text { 1. Paleocene }\end{array}$} & & & & \\
\hline \multirow{3}{*}{$\begin{array}{l}-311.5 \\
- \\
-3099\end{array}$} & $34 \mathrm{R}$ & & & & & \\
\hline & $35 R$ & & & & & \\
\hline & $36 \mathrm{R}$ & & & & & \\
\hline \multirow{5}{*}{\begin{tabular}{|l} 
\\
-348.7 \\
-358.1
\end{tabular}} & $37 R$ & \multirow{5}{*}{$\begin{array}{l}\text { Late } \\
\text { Cretaceous }\end{array}$} & \multirow{3}{*}{\multicolumn{2}{|c|}{ IV }} & & \multirow{3}{*}{ Claystone } \\
\hline & $38 \mathrm{R}$ & & & & & \\
\hline & $39 R$ & & & & & \\
\hline & $40 \mathrm{R}$ & & & & 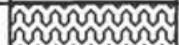 & Yalongin thidito \\
\hline & $41 R$ & & & & 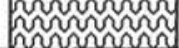 & Volcanic turoiaites \\
\hline & & & & 1 & 寻 & 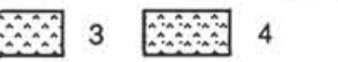 \\
\hline
\end{tabular}

Figure 2. Lithology of the studied interval from Hole 802A. Key to legend: $1=$ volcanic turbidites, $2=$ claystone, $3=$ calcareous chalk, and $4=$ nannofossil chalk. 


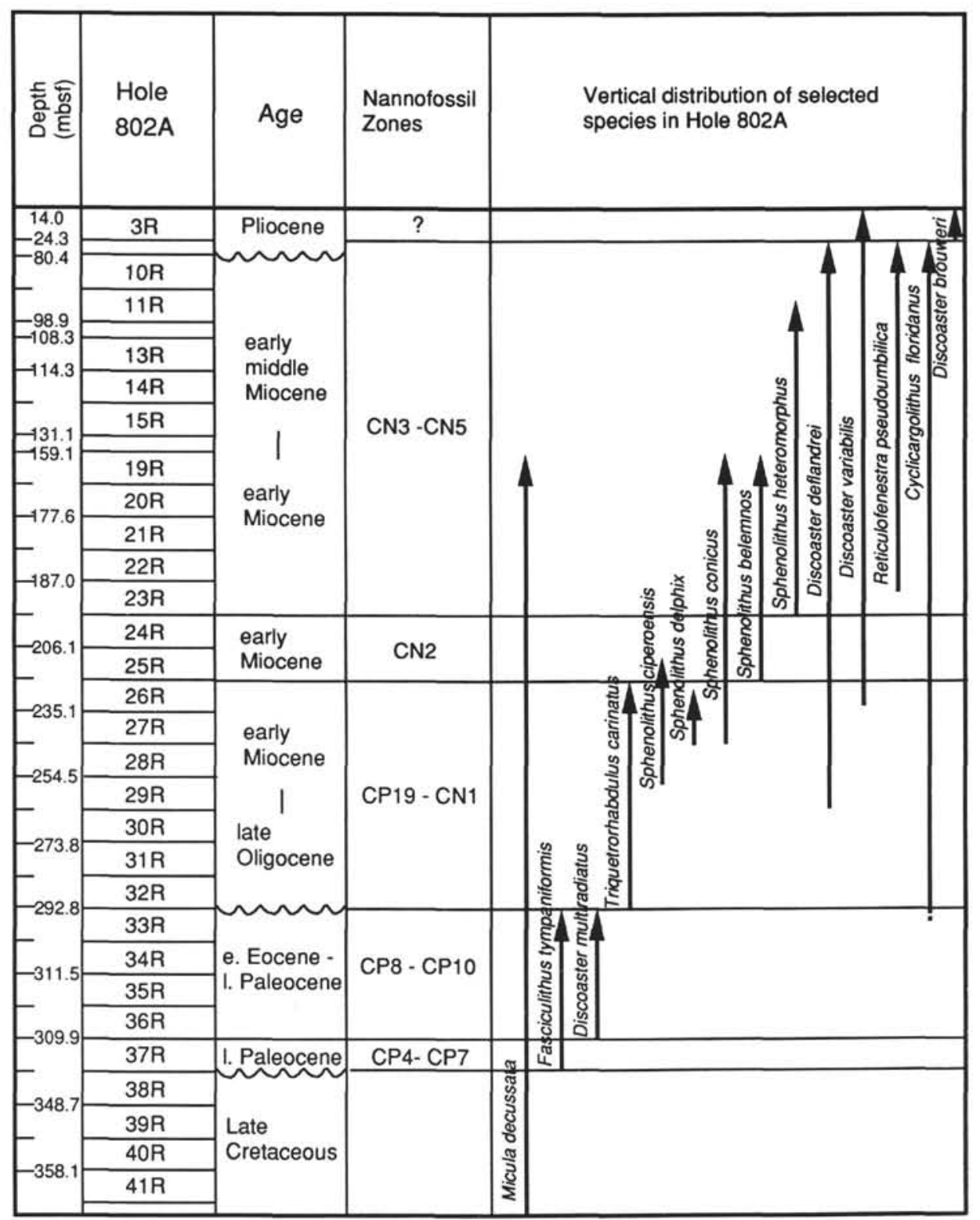

Figure 3. Ranges of selected species and nannofossil zones for Hole 802A.

\section{Zones Fasciculithus tympaniformis to Discoaster nobilis (CP4-CP7)}

Occurrence: Samples 129-802A-37R-CC to -37R-1, 6-7 cm Age: late Paleocene

Core 129-802A-37R is assigned to Zones CP4-CP7 based on the FO of Fasciculithus tympaniformis and Sphenolithus primus in Sample 129-802A-37R-CC, and the FO of Discoaster multiradiatus in Sample 129-802A-36R-1, 29-30 cm. Zones CP4, CP5, CP6, and CP7 cannot be differentiated because of the absence of Heliolithus kleinpellii, Discoaster mohleri, and D. nobilis.

\section{Zones Discoaster multiradiatus to Tribrachiatus orthostylus (CP8-CP10)}

Occurrence: Cores 129-802A-36R through -33R

Age: late Paleocene to early Eocene
Cores 129-802A-36R through -33R are assigned to Zones CP8-CP10 based on the FO of Discoaster multiradiatus in Sample 129-802A-36R1, 29-30 cm, and the LO of Sphenolithus anarrhopus in Sample 129802A-33R-1, 6-7 cm, as well as the FO of Triquetrorhabdulus carinatus in Sample 129-802A-32R-3, 16-17 cm. Discoaster multiradiatus and Fasciculithus tympaniformis also have their LO in Sample 129-802A33R-1, 6-7 cm.

Discussion: The co-occurrence of $C$. californicus (ranging from Zones CP9 to CP11) and Sphenolithus annarhopus (Zones CP6-CP10) may indicate that the top of the interval is equivalent to Zones CP9-CPI0. Other associated species such as $S$. radians (Subzone $\mathrm{CP} 9 \mathrm{~b}$ to Zone $\mathrm{CP} 15$ ) and species having their FO in the upper part of the interval such as $C$. consuetus (Zone CP4 to Subzone CP15b), C. expansus (Zone CP10 to Subzone $\mathrm{CP} 14 \mathrm{a}$ ), and $D$. barbadiensis (Zone CP9 to Subzone CP15b) also support this conclusion. The combined zone cannot be differentiated further into Zones $\mathrm{CP} 8, \mathrm{CP} 9$, and $\mathrm{CP} 10$ because of the absence 
of marker species D. diastypus, Tribrachiatus contortus, $T$. orthostylus, and D. lodoensis.

\section{Zones Sphenolithus ciperoensis to Triquetrorhabdulus carinatus (CP19-CN1)}

Occurrence: Sample 129-802A-32R-3, 16-17 cm, through Core 129-802A-26R

Age: late Oligocene-earliest Miocene

Sample 129-802A-32R-3, 16-17 cm, through Core 129-802A26R are assigned to Zones CP19-CN1 on the basis of the FO of Sphenolithus ciperoensis from Sample 129-802A-29R-1, 3-4 cm; the FO of Triquetrorhabdulus carinatus from Sample 129-802A-32R-3, $16-17 \mathrm{~cm}$; and the FO of $S$. belemnos from Sample 129-802A-25RCC. The FOs of S. delphix (in Sample 129-802A-27R-3, 60-61 cm) and $S$. conicus (in Sample 129-802A-27R-5, 32-33 cm) in the upper part of the interval also support the current assignment.

Discussion: The poor preservation at this site causes severe problems, such as the fact that the FO of Sphenolithus distentus is much higher stratigraphically than the FO of Triquetrorhabdulus carinatus and the occurrences of $S$. ciperoensis and $S$. delphix are sporadic and shortened. This situation makes it impossible to delineate the boundary between Zones CP19 and CN1 or between Subzones CN1a, CN1b, and CN1c. Subzone CN1c may be missing in this section, as suggested by the absence of the marker species Discoaster druggii and Rhabdothorax serratus. Because sediments assigned to the top of Zone CP10 are overlain directly by sediments containing Zone CP19, a hiatus is recognized between Samples 129-802A-33R-1, 6-7 cm, and $-32 \mathrm{R}-3,16-17 \mathrm{~cm}$, based on the absence of Zones CP10 to CP18.

\section{Sphenolithus belemnos Zone (CN2)}

Occurrence: Section 129-802A-25R-CC to Sample 129-802A$24 \mathrm{R}-1,12-13 \mathrm{~cm}$.

Age: early Miocene

Samples $129-802 \mathrm{~A}-25 \mathrm{R}-\mathrm{CC}$ through $-24 \mathrm{R}-1,12-13 \mathrm{~cm}$, are assigned to Zone CN2 on the basis of the FO of Sphenolithus belemnos in Sample 129-802A-25R-CC and the FO of $S$. heteromorphus in Sample 129-802A-23R-2, 87-88 cm.

\section{Zones Helocosphaera ampliapera to Discoaster kugleri (CN3-CN5)}

Occurrence: Samples 129-802A-23R-2, 87-88 cm, to $-10 \mathrm{R}-3$, $6-7 \mathrm{~cm}$

Age: early Miocene to early middle Miocene

Samples 129-802A-23R-2, 87-88 cm, through -10R-3, 6-7 cm, may be assigned to Zones CN3-CN5 based on the FO of Sphenolithus heteromorphus in Sample 129-802A-23R-2, 87-88 cm, at the bottom of the interval; and the top of the interval is tentatively allocated by the co-occurrence of Cyclicargolithus floridanus and Discoaster deflandrei in Sample 129-802A-10R-3, 6-7 cm.

Discussion: Although the dissolution-susceptible species Helicosphaera ampliaperta is absent from the base of this interval, the co-occurrence of Sphenolithus belemnos and S. heteromorphus suggests the existence of Zone CN3. The occurrence of Reticulofenestra pseudoumbilica from Samples 129-802A-23R-1, 8-9 cm, through $-10 \mathrm{R}-3,6-7 \mathrm{~cm}$, also provides support for the assignment of the interval to Zones CN3-CN5. Zones CN4 and CN5 cannot be delineated from the combined zone because the marker species Discoaster kugleri was not observed in this interval, and the LO datums of Discoaster deflandrei and Sphenolithus heteromorphus are not very useful for zonation because of the extensive reworking. Above Sample 129-802A-19R-2, 33-34 cm, the nannofossil assemblages decrease dramatically in both species abundance and diversity, and samples that are barren of nannofossils increase in number as well.
The interval above Sample 129-802A-10R-3, 6-7 cm, is barren of nannofossils except for one sample (Sample 129-802A-3R-CC), which yielded rare specimens of Discoaster brouweri, D. variabilis, and $D$. sp. We assume, therefore, that the top of the interval is probably Pliocene in age.

\section{Hole 801A}

Nannofossils listed below were found in the only sample available to us (129-801A-5R-1, 60-61 cm). The assemblage consists of both upper Paleogene and reworked Upper Cretaceous species. The occurrence of Fasciculithus tympaniformis from the mixed assemblage may suggest that the sample is not older than late early Paleocene in age.

All species listed below are rare in the sample except for Coccolithus pelagicus, which is abundant. They are Broinsonia parca constricta, B. parca expansus, Chiasmolithus sp., C. californicus, C. danicus, C. edwardsii, Chiastozygus litterarius, Coccolithus pelagicus, Cretarhabdus crenulatus, Cribrosphaerella ehrenbergii, Cruciplacolithus tenuis, Discoaster mohleri, Discoaster multiradiatus, Ellipsolithus macellus, Ericsonia subpertusa, Fasciculithus lillianae, F. pileatus, F. tympaniformis, Heliolithus bukryi, Markalius inversus, Manivitella pemmatoidea, Microrhabdulus decoratus, Micula decussata, M. murus, M. prinsii, Prediscosphaera cretacea, Quadrum gartneri, $Q$. gothicum, $Q$. sissinghii, Tegumentum stradneri, and Watznauris barnesae.

\section{ACKNOWLEDGMENTS}

We wish to extend our warmest thanks to S.W. Wise, Jr., from Florida State University, Tallahassee, for his continuous help and strong encouragement during the research and manuscript preparation. We also thank M. P. Aubry from Woods Hole Oceanographic Institution, Massachusetts, for her critical review of the manuscript and E. Erba (Department of Earth Sciences, Via Mangiagalli 34, 1-20133 Milano, Italy) for her comments. Eric de Kaenel kindly examined several critical samples. Andrew Fisher (ODP staff scientist for Leg 129) assisted in many ways, and John Firth (ODP staff scientist) also provided helpful comments on the manuscript. The SEM for this work was operated by Kim Riddle from Florida State University. This study was supported by JOI-USSAC funds with laboratory equipment provided by NSF Grant No. DPP-91-16480 to S.W. Wise, Jr.

\section{REFERENCES}

Aubry, M.-P., 1986. Paleogene calcareous nannoplankton biostratigraphy of northwest Europe. Palaeogeogr., Palaeoclimatol., Palaeoecol., $55: 276-334$

, 1989. Phylogenetically based calcareous nannofossil taxanomy: implications for interpretation of geological events. In Crux, J.A., and van Heck, S.E. (Eds.) Nannofossils and Their Applications: London (Ellis Horwood) 21-40.

Backman, J., and Hermelin, J.O.R., 1986. Morphometry of the Eocene nannofossil R.umbilica lineage and its biochronological consequences. Paleogeogr., Paleoclimatol., Paleoecol., 57:103-106.

Berggren, W.A., Kent, D.V., and Flynn, J.J., 1985. Jurassic to Paleogene: Part 2. Paloegene geochronology and chronostratigraphy. In Snelling, N.J. (Ed.), The Chronology of the Geological Record. Geol. Soc. London Mem., 10:141-195.

Berggren, W.A., Kent, D.V., and Van Couvering, J.A., 1985. The Neogene: Part 2. Neogene geochronology and chronostratigraphy. In Snelling, N.J. (Ed.), The Chronology of the Geological Record. Geol. Soc. London Mem., 10:211-260.

Erba, E., and Covington, J.M., in press. Calcareous nannofossil biostratigraphy of Mesozoic sediments recovered from the western Pacific Ocean, Leg 129. In Larson, R.L., Lancelot, Y., et al., 1992. Proc. ODP, Sci. Results, 129: College Station, TX (Ocean Drilling Program).

Lancelot, Y., Larson, R.L., et al., 1990. Proc. ODP, Init. Repts., 129: College Station, TX (Ocean Drilling Program). 
Okada, H., and Bukry, D., 1980. Supplementary modification and introduction of code numbers to the low-latitude coccolith biostratigraphic zonation (Bukry, 1973; 1975). Mar. Micropaleontol., 5:321-325.

Perch-Nielsen, K., 1985. Cenozoic calcareous nannofossils. In Bolli, H.M. Saunders, J.B., and Perch-Nielsen, K. (Eds.), Plankton Stratigraphy: Cambridge (Cambridge Univ. Press), 427-553.

Wei, W., 1989. Heliolithus bukryi, new upper Paleocene calcareous nannofossil species. INA Newsl., 10:90-93.

Date of initial receipt: 28 April 1992

Date of acceptance: 17 July 1992

Ms 130B-060

\section{Appendix}

Biantholithus sparsus Bramlette and Martini (1964)

Bramletteius serraculoides Gartner (1969)

Chiasmolithus californicus (Sullivan, 1964) Hay and Mohler (1967)

Chiasmolithus consuetus (Bramlette and Sullivan, 1961) Hay and Mohler (1967)

Chiasmolithus edwardsii (Romein, 1979) Van Heck and Prins (1987)

Chiasmolithus expansus (Bramlette and Sullivan, 1961) Gartner (1970)

Chiasmolithus grandis (Bramlette and Riedel, 1954) Radomski (1968)

Coccolithus formosus (Kamptner, 1963) Wise (1973)

Coccolithus pelagicus (Wallich, 1877) Schiller (1930)

Cruciplacolithus primus Perch-Nielsen (1977)

Cruciplacolithus tenuis (Stradner, 1961) Hay and Mohler in Hay et al. (1967)

Cyclagelosphaera abisectus (Muller, 1970) Wise (1973)

Cyclicargolithus floridanus (Roth and Hay in Hay et al., 1967) Bukry (1971)

Dictyococcites bisectus (Hay, Mohler and Wade, 1966) Bukry and Percival (1971)

Discoaster barbadiensis Tan (1927)

Discoaster bifax Bukry (1971)

Discoaster brouweri Tan (1927) emend. Bramlette and Riedel (1954)

Discoaster deflandrei Bramlette and Riedel (1954)

Discoaster exilis Martini, Bramlette and Riedel (1963)

Discoaster mohleri Bukry and Percival (1971)

Discoaster multiradiatus Bramlette and Riedel (1954)

Discoaster saipanensis Bramlette and Riedel (1954)

Discoaster variabilis Martini and Bramlette (1963)

Discoaster woodringii Bramlette and Riedel (1954)

Ellipsolithus macellus (Bramlette and Sullivan, 1961) Sullivan (1964)
Ericsonia subpertusa Hay and Mohler (1967)

Fasciculithus bobii Perch-Nielsen (1971)

Fasciculithus involutus Bramlette and Sullivan (1961)

Fasciculithus lillianae Perch-Nielsen (1971)

Fasciculithus pileatus Bukry (1973d)

Fasciculithus tympaniformis Hay and Mohler in Hay et al. (1967)

Heliolithus bukryi Wei (1989)

Heliolithus kleinpellii Sullivan (1964)

Markalius inversus (Deflandre in Deflandre and Fert, 1954) Bramlette and Martini (1964)

Placozygus sigmoides (Bramlette and Sullivan, 1961) Romein (1979)

Pontosphaera multipora (Damptner, 1948) Roth (1970)

Pseudotriquetrorhabdulus inversus (Bukry and Bramlette, 1969b) Wise in Wise and Constans (1976)

Reticulofenestra hillae Bukry and Percival (1971)

Reticulofenestra pseudoumbilica (Gartner, 1967) Gartner (1969)

Reticulofenestra reticulata (Gartner and Smith, 1967) Roth and Thierstein (1972)

Reticulofenestra samodurovii (Hay, Mohler and Wade, 1966) Roth (1970)

Reticulofenestra umbilica (Levin, 1965) Martini and Ritzkowski (1968)

Sphenolithus anarrhopus Bukry and Bramlette (1969)

Sphenolithus belemnos Bramlette and Wilcoxon (1967)

Sphenolithus celsus Haq (1971)

Sphenolithus ciperoensis Bramlette and Wilcoxon (1967)

Sphenolithus conicus Bukry (1971)

Sphenolithus delphix Bukry (1973)

Sphenolithus distentus (Martini, 1965) Bramlette and Wilcoxon (1967)

Sphenolithus editus Perch-Nielsen in Perch-Nielsen et al. (1978)

Sphenolithus heteromorphus Deflandre (1953)

Sphenolithus moriformis (Brönnimann and Stradner, 1960) Bramlette and Wilcoxon (1967)

Sphenolithus obtusus Bukry (1971)

Sphenolithus predistentus Bramlette and Wilcoxon (1967)

Sphenolithus primus Perch-Nielsen (1971)

Sphenolithus pseudoradians Bramlette and Wilcoxon (1967)

Sphenolithus radians Deflandre in Grassé (1952)

Sphenolithus spiniger Bukry (1971)

Sphenolithus umbrellus (Bukry 1971) Knüttel (1986)

Toweius eminens (Bramlette and Sullivan, 1961) Perch-Nielsen (1971)

Triquetrorhabdulus carinatus Martini (1965) 


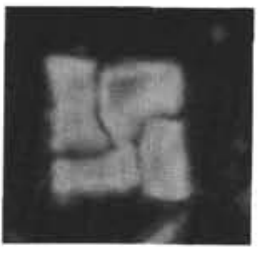

1

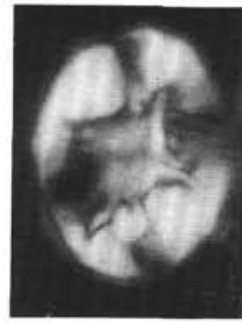

6

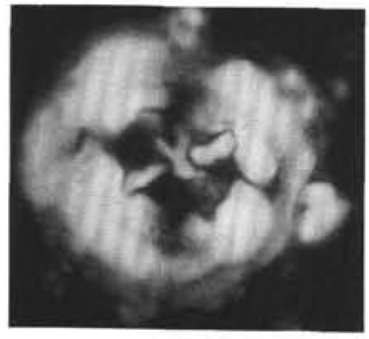

12

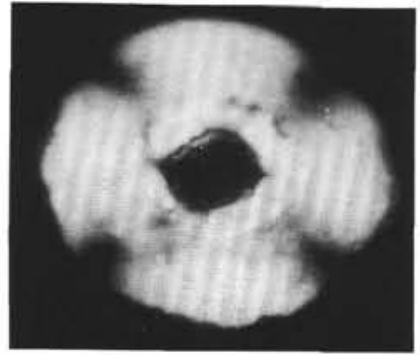

16

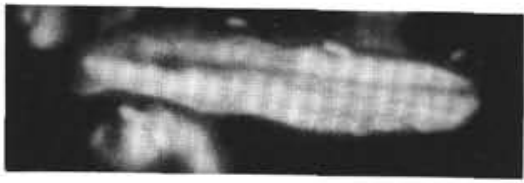

19

2

7

13
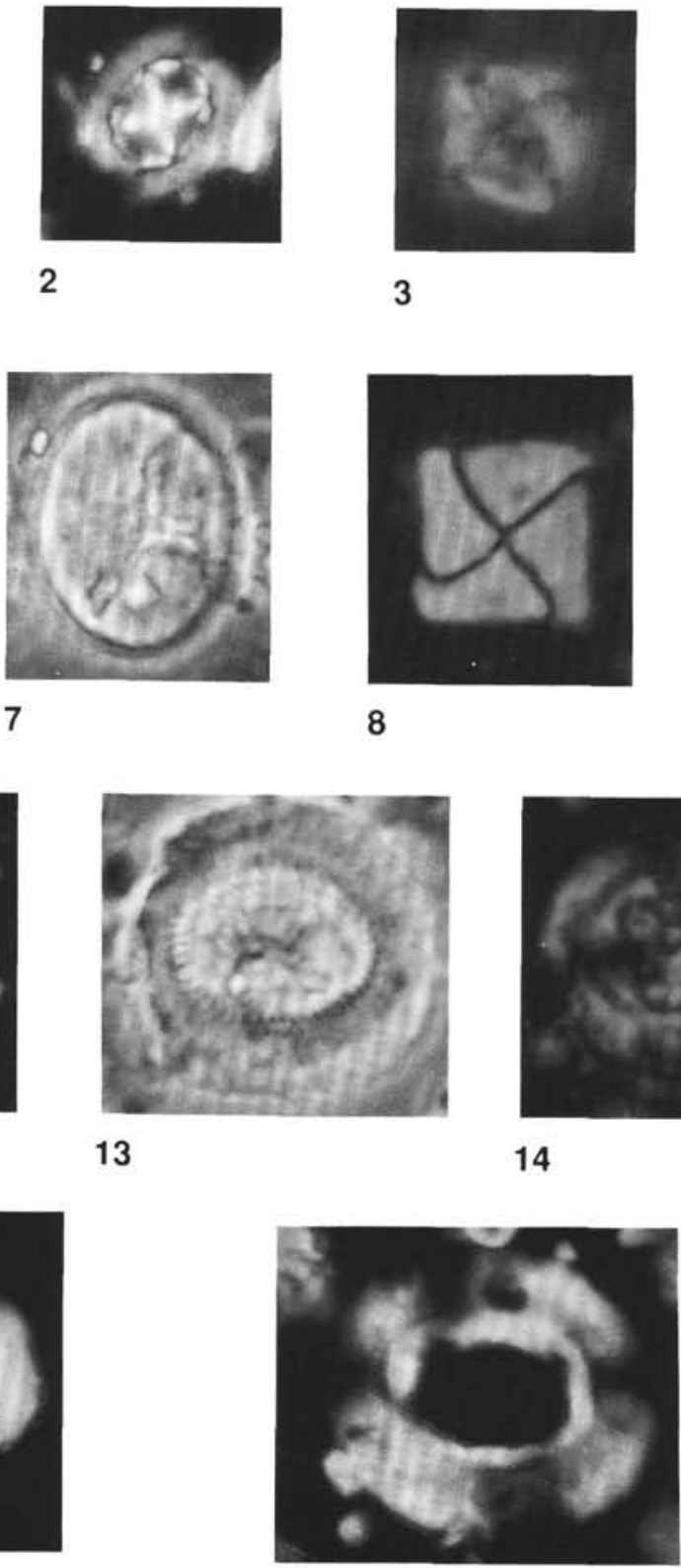

17

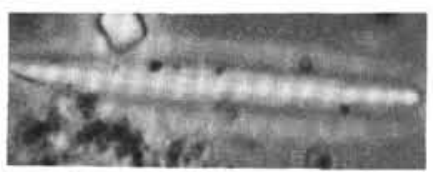

20

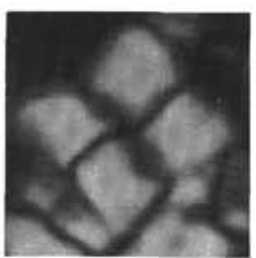

4

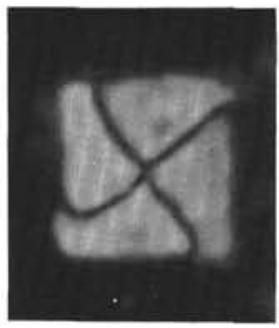

8

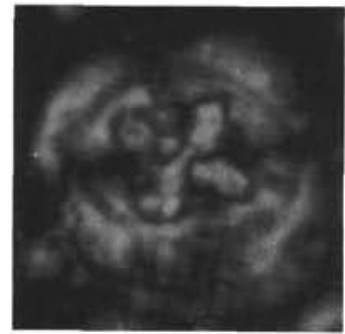

14

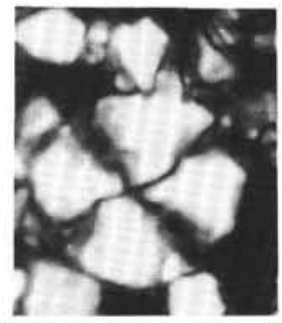

9

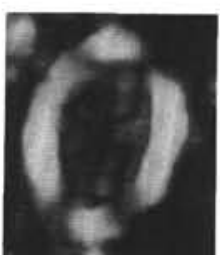

5

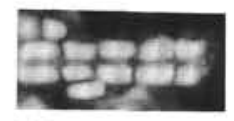

10

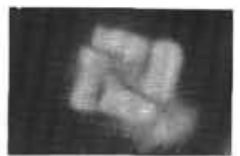

11

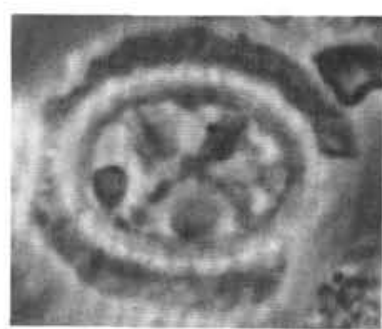

15

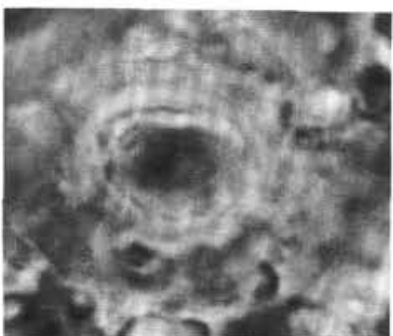

18

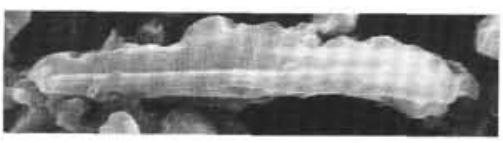

21

Plate 1. All magnifications 2100x, unless otherwise specified. 1. Micula sp. cf. M. murus, Sample 129-802A-33R-1,94-96 cm. 2. Prediscosphaera cretacea, Sample 129-802A-36R-2, 29-30 cm. 3,11. Micula decussata, (3) Sample 129-801A-5R-1,60-61 cm; (11) Sample 129-802A-33R-CC. 4. Quadrum gothicum, Sample 129-802A-34R-1, 62-65 cm. 5. Arkhangelskiella cymbiformis, Sample 129-802A-33-R-CC. 6, 7. Eiffellithus turriseiffelii, Sample 129-802A-31RCC. 8. Micula sp. cf. $M$ staurophora, Sample 129-802A-34R-1, 62-65 cm. 9. Watznaueria barnesae, Sample 129-802A-38R-CC. 10. Microrhabdulus decoratus Sample 129-802A-33R-CC. 12, 13. Chiasmolithus californicus, Sample 129-802A-36R-1, 19-20 cm. 14. C. consuetus, Sample 129-802A-35RCC. 15. C. expansus, Sample 129-802A-26R-CC. 16. Reticulofenestra hillae, Sample 129-802A-25R-CC. 17, 18. R. umbilica, Sample 129-802A-31R-2, $32-33 \mathrm{~cm}$. 19, 20. Triquetrorhabdulus carinatus, (19) Sample 129-802A-26R-CC; (20) Sample 129-802A-27R-1, 44-45 cm. 21. Pseudotriquetrorhabdulus inversus, SEM, magnification 3000×, Sample 129-802A-32R-1, 6-7 cm. 


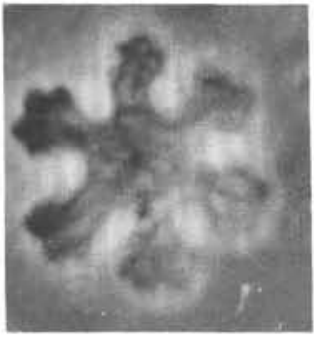

1

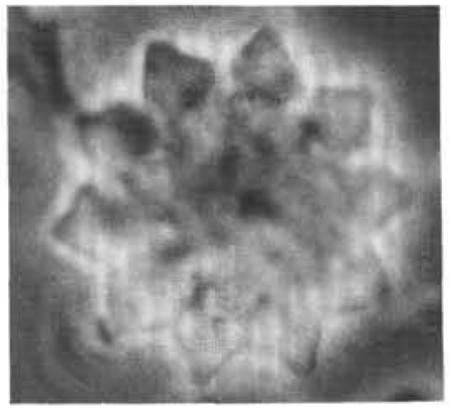

6

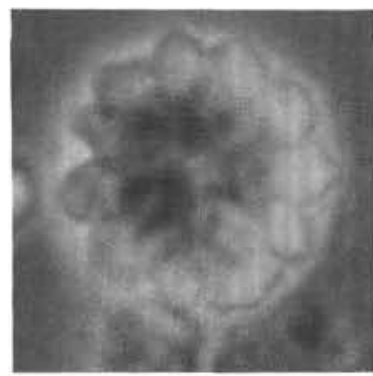

10

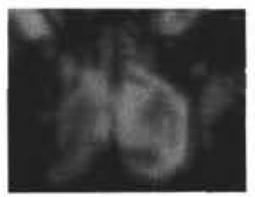

14

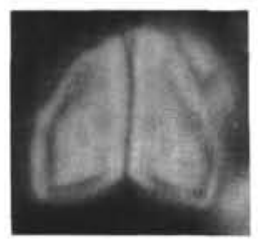

20

2

15

21
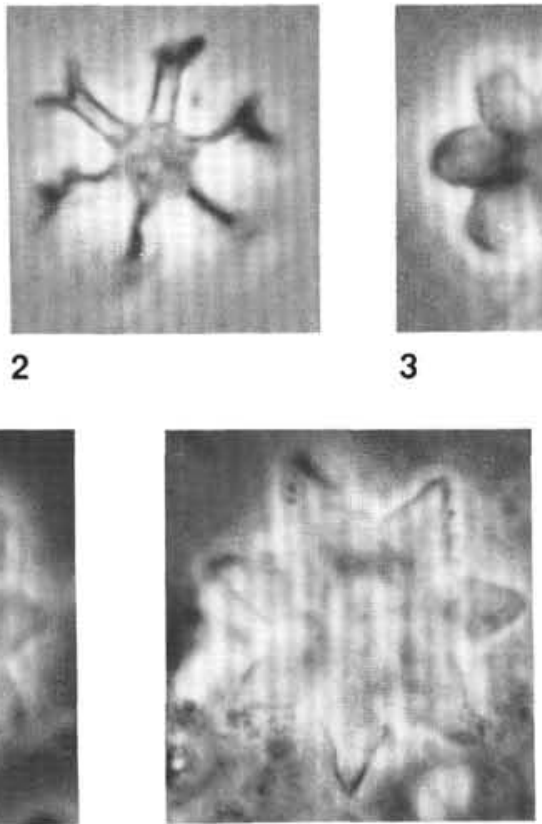

7

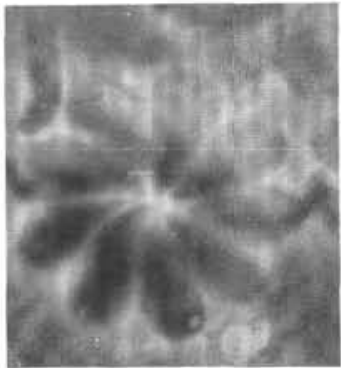

11
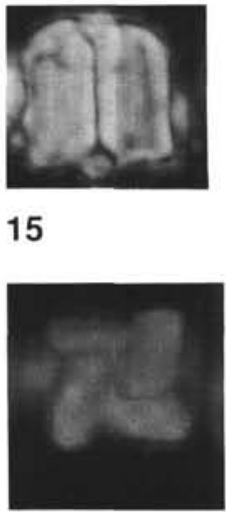

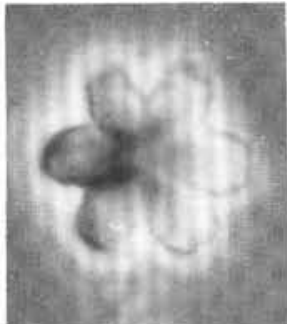

3

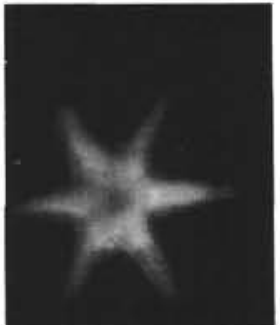

4

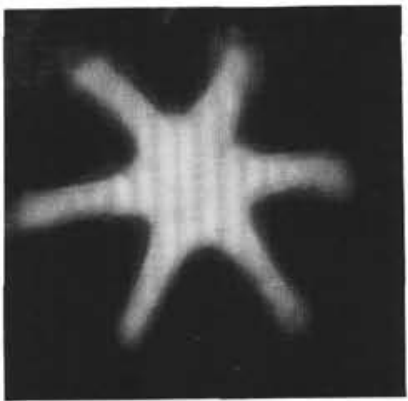

8

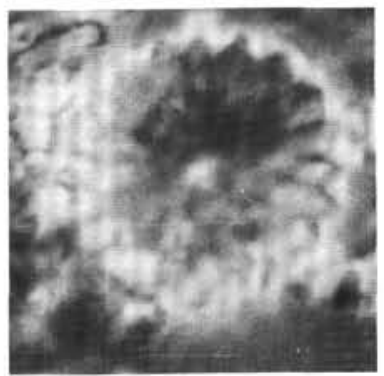

12

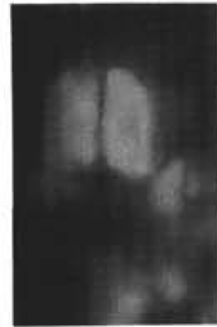

5

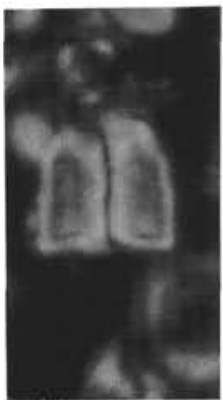

9

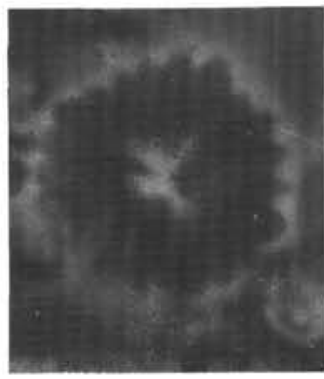

13

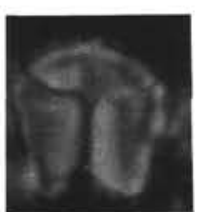

17

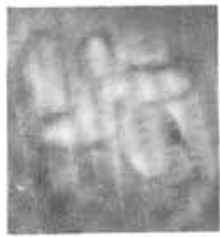

23

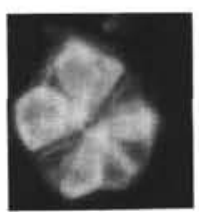

18

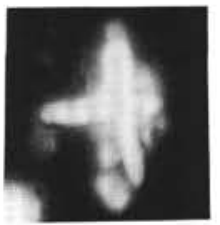

24

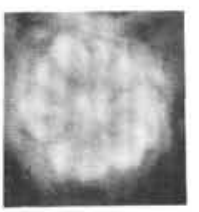

19

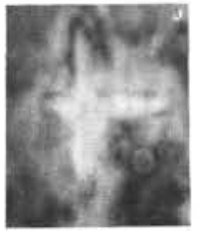

25

Plate 2. All magnifications 2100x. 1. Discoaster deflandrei, Sample 129-802A-25R-1, 25-26 cm. 2. D. variabilis, Sample 129-802A-11R-1, 113-114 cm. 3. Discoaster woodringii, Sample 129-802A-27R-4, 74-75 cm. 4, 8. D. brouweri, Sample 129-802A-3R-CC. 5, 9. Fasciculithus tympaniformis, (5) Sample 129-802A-36R-1, 18-19 cm; (9) Sample 129-801A-5R, 60-61 cm. 6, 10. Discoaster barbadiensis, (6) Sample 129-802A-26R-CC; (10) Sample 129-802A5R, $60-61 \mathrm{~cm}$. 7. D. saipanensis Sample 129-802A-27R-1, 44-45 cm. 11. D. mohleri, Sample 129-802A-5R-1, 60-61 cm. 12, 13. D. multiradiatus, (12) Sample 129-802A-32R-3, 6-7 cm.; (13) Sample 129-801A-5R-1, 60-61 cm. 14. Fasciculithus lillianae, Sample 129-802A-35R-CC. 15. F. involutus, Sample 129-802A-31R-2, 32-33 cm. 16. F. bobii, Sample 129-802A-33R-2, 1-2 cm. 17. F. pileatus, Sample 129-802A-35R-CC. 18, 19. Fasciculithus sp., Sample 129-802A-36R-1, 18-19 cm. 20. F. hayi, Sample 129-802A-35R-CC. 21. Micula murus, Sample 129-801A-5R-1, 60-61 cm. 22, 23. Micula prinsii, Sample 129-801A-5R-1, 60-61 cm. 24, 25. Quadrum sissinghii, Sample 129-801A-5R-1, 60-61 cm. 


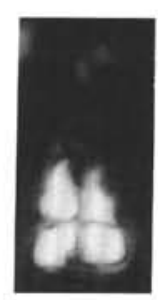

1

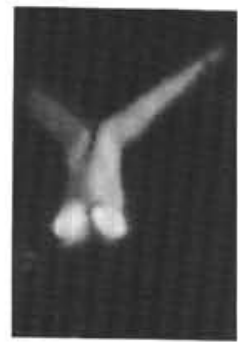

7

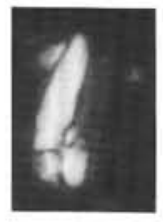

12

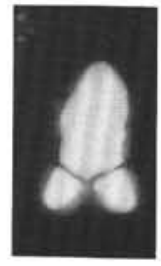

19

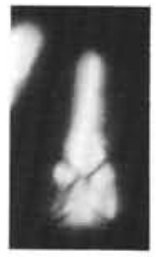

26

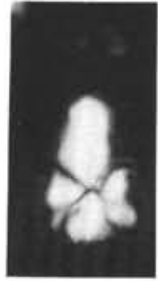

2

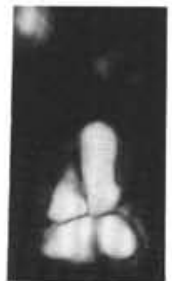

3

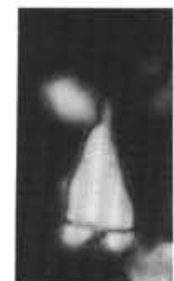

4

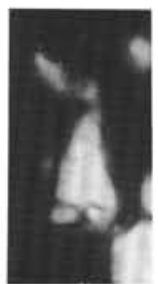

5

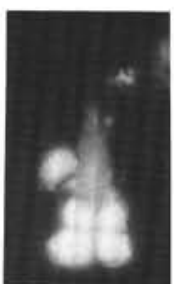

6

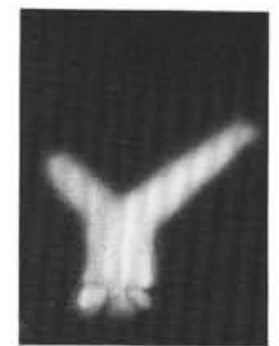

8

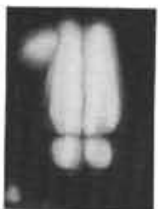

13

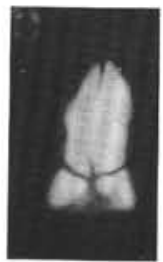

20

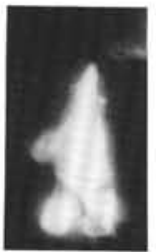

27

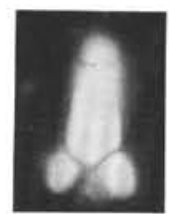

14

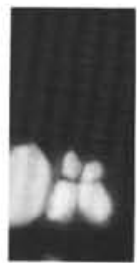

21

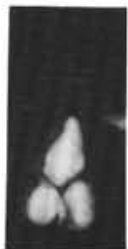

28

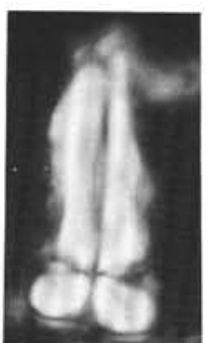

9

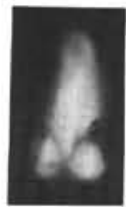

15

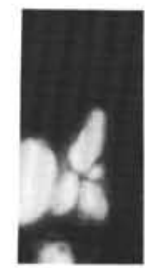

22

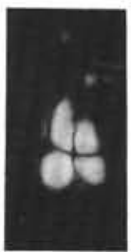

29

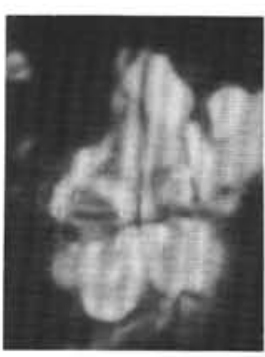

10

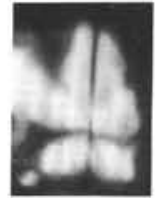

16

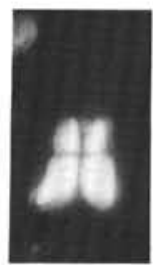

23

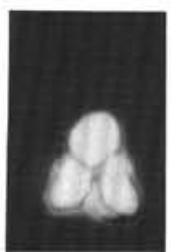

30

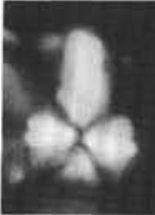

17

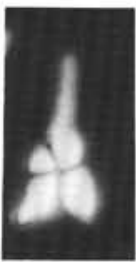

24

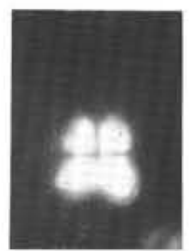

31

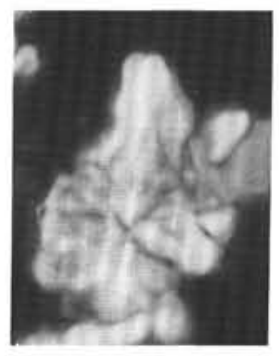

11

Plate 3. All magnifications 2100x. 1-3, 21-22. Sphenolithus anarrhopus, (1-3) Sample 129-802A-33R-2, 1-2 cm; (21) and (22) Sample 129-802A-25R-CC. 4, 5, 25. S. predistentus, (4) and (5) Sample 129-802A-28R-CC; (25) Sample 129-802A-31R-2, 5-6 cm. 6. S. heteromorphus, Sample 129-802A-19R-2, 33-34 cm. 7, 8. S. distentus, Sample 129-802A-25R-CC. 9-11. S. pseudoradians, Sample 129-802A-27R-5, 108-109 cm. 12, 13. S. celsus, Sample 129802A-29R-3, 73-74 cm. 14, 15. S. distentus, Sample 129-802A-25R-CC. 16-18. S. radians, (16) and (17) Sample 129-802A-27R-CC; (18) Sample 129-802A32R-1, 6-7 cm. 19, 20. S. obtusus, Sample 129-802A-25R-CC. 23, 24. S. belemnos, Sample 129-802A-25R-CC. 26, 27. S. ciperoensis, (26) Sample 129-802A-27R-3, 60-61 cm; (27) Sample 129-802A-29R-1, 3-4 cm. 28, 29. S. spiniger, Sample 129-802A-30R-1, 69-70 cm. 30. S. moriformis, Sample 129-802A-25R-CC. 31, 32. S. editus, Sample 129-802A-19R-2, 33-34 cm. 


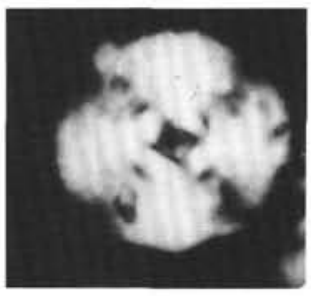

1

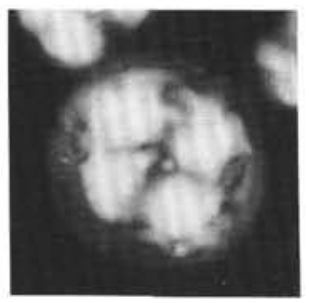

6

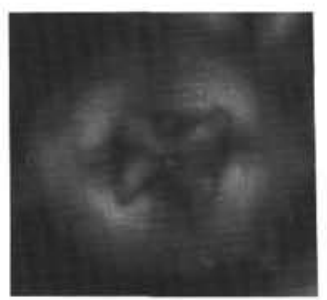

10

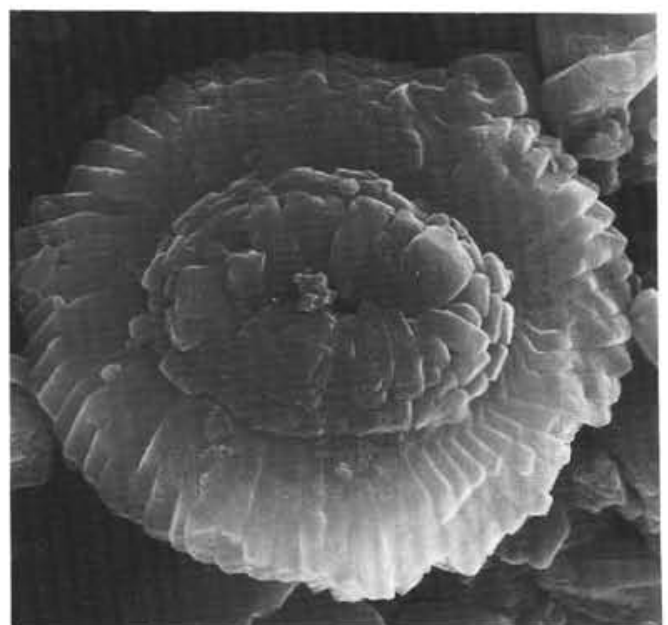

15

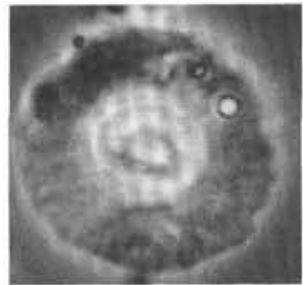

2

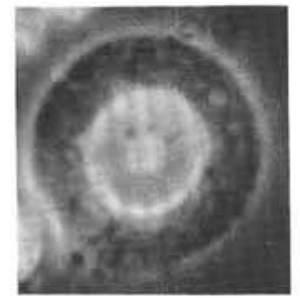

7

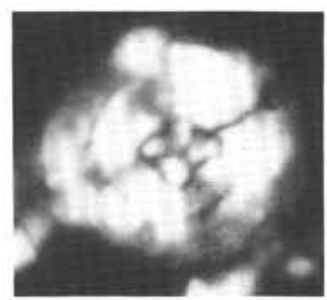

11

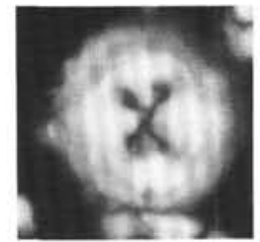

19

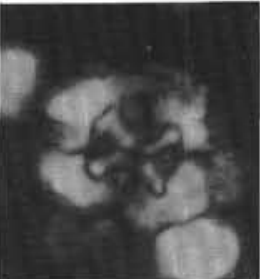

3

8

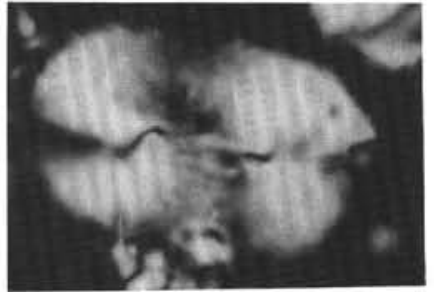

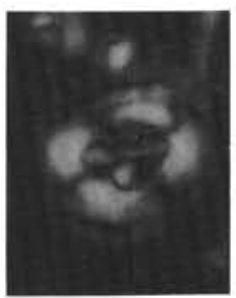

12

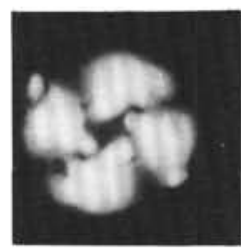

16

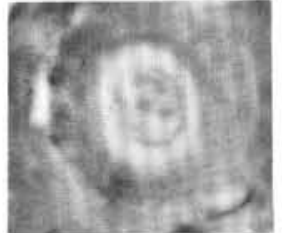

20

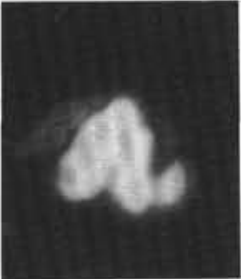

5

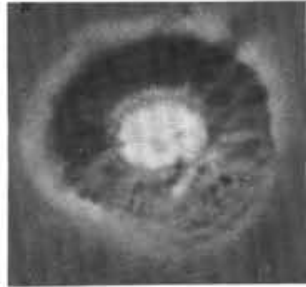

9

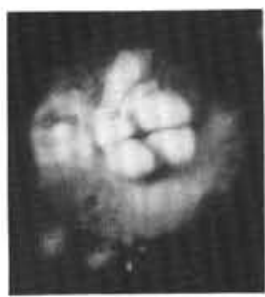

14

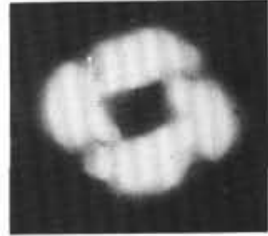

18

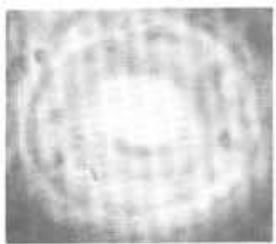

21

Plate 4. All magnifications 2100x, unless otherwise specified. 1, 2, 4. Cyclicargolithus abisectus, (1) and (2) Sample 129-802A-27R-4, 74-75 cm, (4) Sample 129-802A-25R-CC. 3. Chiasmolithus edwardsii, Sample 129-802A-33R-1, 94-95 cm. 5. Sphenolithus umbrellus, Sample 129-802A-28R-CC. 6, 7. Coccolithus formosus, Sample 129-802A-26R-2, 100-101 cm. 8. Ellipsolithus macellus, Sample 129-802A-33R-1, 6-7 cm. 9, 14. Markalius inversus, Sample 129-802A-33R-1, 94-95 cm. 10. Chiasmolithus danicus, Sample 129-801A-5R-1, 60-61 cm. 11. Cruciplacolithus tenuis, Sample 129-802A-36R-1, $18-19 \mathrm{~cm}$. 12, 13. Cruciplacolithus primus, (12) Sample 129-802A-35R-CC; (13) Sample 129-802A-33R-1, 94-95 cm. 15. Dictyococcites bisectus, Sample 129-802A-32R-1, 6-7 cm., SEM, magnification 6500x. 16, 17. Cyclicargolithus floridanus, Sample 129-802A-27R-4, 74-75 cm. 18, 21. Reticulofenestra pseudoumbilica, (18) Sample 129-802A-23R-1, 8-9 cm; (21) Sample 129-802A-11R-1, 120-121 cm. 19, 20. Toweius eminens, Sample 129-802A-27R-CC. 